\title{
CYTOGENETIC EFFECT OF SUPERMETHRIN IN PIG AND CATTLE PERIPHERAL LYMPHOCYTES
}

\author{
J. DIANOVSKÝ, K. ŠIVIKOVÁ \\ Department of Veterinary Genetics, University of Veterinary Medicine, Košice, Slovak Republic
}

Received July 22, 1996

Accepted February 10, 1997

\begin{abstract}
Dianovský J., K. Šiviková: Cytogenetic Effect of Supermethrin in Pig and Cattle Lymphocytes. Acta vet. Brno,1997, 66:33-38.

The synthetic pyrethroid insecticide supermethrin (RS)-alpha-cyano-3-phenoxybenzyl-(1RS)cis-3 (2,2-dichlorvinyl)-2,2-dimethyl cyclopropane carboxylate, was tested for its clastogenic ability in in vitro assays.

Cultured pig and cattle peripheral lymphocytes were used for in vitro clastogenicity evaluation in the absence of S-9 mix. The final concentrations were $6 \times 10^{-6} \mathrm{M}, 6 \times 10^{-5} \mathrm{M}$ and $6 \times 10^{-4} \mathrm{M}$. No significant differences were detectable in supermethrin's clastogenic potency at concentrations of $6 \times 10^{-6} \mathrm{M}$ and $6 \times 10^{-5} \mathrm{M}$, respectively, in cattle. The highest concentration was positive $(\mathrm{P}<0.05)$ and a decrease of mitotic index (MI) was also observed. The pig peripheral lymphocytes showed clastogenic effect $(\mathrm{P}<0.05)$ at concentrations $6 \times 10^{-5} \mathrm{M}$ and $6 \times 10^{-4} \mathrm{M}$. Cytotoxic effect expressed by MI value was also more perspicuous.

Supermethrin was investigated for the induction of sister chromatide exchanges (SCE) in pig and cattle peripheral lymphocytes, but inadequate results of genotoxic potency not corresponding to the concentrations were found. The tested pyrethroid was characterized as more toxic than clastogenic or genotoxic.
\end{abstract}

Pyrethroids, genotoxicity, in vitro, pig and cattle lymphocytes

Supermethrin, a synthetic derivative of natural pyrethrin insecticides, belongs to the group of so-called pyrethroids. Supermethrin is a type II pyrethroid of Czech origin (Spolana, Neratovice) and similar in structure to cypermethrin. Chemically it is (RS)-alpha-cyano-3phenoxybenzyl-(1RS)-cis-3(2,2-dichlorvinyl)- 2,2-dimethyl cyclopropane carboxylate<smiles>CC1(C)C(C=C(Cl)Cl)C1C(=O)OC(C#N)c1cccc(Oc2ccccc2)c1</smiles>

Fig. 1. Chemical structure of supermethrin

(Fig. 1). The pyrethroids possess many desirable properties including high toxicity to target objects, low toxicity for mammals and good biodegradation activity in the environment. There is a number of reports dealing with their pharmacokinetic (Eriksson and Nordberg 1990), metabolic degradation (Crawford et al. 1982, Legáth et al. 1992) and allergenicity (Hoellinger et al. 1987). Although extensive studies of the general toxicity of pyrethroids have been undertaken, there are inconsistent reports dealing with their genotoxicity.

Experiments evaluating the mutagenicity of permethrin to Salmonella showed no detectable effect (Miyamoto 1976). However, a significant induction of micronuclei (MN) was found in mouse bone marrow cells after cypermethrin administration (A mer and Aboulela 1985). Subsequent investigations (Batiste-Alentorn et al. 1987) demonstrated that cypermethrin was able to induce a small increase in sex-linked recessive lethal mutation after adult injection or larval feeding in Drosophila. Other authors (Puig et 
al. 1989) reported that cypermethrin did not induce genotoxic damage in human lymphocyte culture. Chromosome aberrations (CA) and sister chromatide exchanges (SCE) were used in this estimation; however, SCE assay (B achitova and Pashin 1988) also supported the genotoxic properties of cypermethrin. This test also included the studies of micronuclei (MN) in Chinese hamster V-79 cells in vitro. All of these chemicals are the derivates of technical cypermethrin, different in proportions of cis and trans isomers or are the secondary technologic products. To provide the additional mutagenicity data, we studied the CA and SCE frequencies induced in pig and cattle cultured lymphocytes after supermethrin administration.

\section{Materials and Methods}

Supermethrin is a Czech derivate of $\alpha$ cypermethrin. Its general formula is $\mathrm{C}_{22} \mathrm{H}_{19} \mathrm{O}_{3} \mathrm{NCl}_{2}$ with molecular weight of 416.32 . Its water solubility is poor $(1 \mathrm{mg} / \mathrm{ml})$ while its solubility in organic solvent (mainly xylene) is good. At $147^{\circ} \mathrm{C}$ it is stable for $76 \mathrm{~h}$. Dimethylsulphoxide (DMSO, Sigma) was used as an organic solvent for supermethrin at a dose $0.5 \%$ of cultivation volume. The same amount of DMSO served as a control after its negative cytotoxic and genotoxic influence to compare to the untreated cultures.

Lymphocyte cultures were established by adding $0.5 \mathrm{ml}$ of heparinized whole blood from 2 healthy donors (Slovak pied cattle and Landrace pig) to $10 \mathrm{ml}$ of chromosome medium RPMI 1640 supplemented with $15 \%$ fetal calf serum and antibiotics (penicillin $250 \mathrm{U} / \mathrm{ml}$ and streptomycin $250 \mu \mathrm{g} / \mathrm{ml}$ ). The lymphocyte division was stimulated with $2 \%$ phyto-haemagglutinin, (PHA, Welcome) and also $1 \%$ concanavalin (Fluka) for the cattle lymphocytes. Two parallel cultures for each test concentration were used. Experiments were performed in whole-blood (Cantelli-Forti et al. 1988) to take advantage of self-contained activating system of the erythrocytes. All cultures were grown for $72 \mathrm{~h}$, out of that the last $24 \mathrm{~h}$ with tested chemical agent for CA and SCE assays. The pig and cattle lymphocytes were exposed to the test chemical at concentrations of $6 \times 10^{-6}, 6 \times 10^{-5}$ or $6 \times 10^{-4} \mathrm{M}$. One hundred well-spread metaphases were scored for each concentration and donor for CA and 50 second metaphases for SCE assays, respectively, using the percentage of aberrant cells and breaks frequencies as an arbitrary markers for clastogenicity. MI was calculated in 1000 lymphocytes for one donor.

For the SCE assays 5-bromo-2-deoxyuridine (BUdR, Sigma) was added $24 \mathrm{~h}$ after initiation to all cultures reaching at a final concentration of $12.5 \mu \mathrm{g} / \mathrm{ml}$. Slides were prepared by the conventional technique and stained with the fluorescence plus Giemsa staining (FPG) method according to Perry and Wolff (1974).

The whole testing system has been constructed to achieve more complexed results dealing with supermethrin`s clastogenic potency by in vitro (CA and SCE) assays using the standard methods for genotoxicity detection.

Differences in CA by in vitro were verified according to Student's t-test and also chi test. ANOVA was utilized for the SCE assay.

\section{Results}

The clastogenic effects of supermethrin expressed through chromosomal damage after addition to cultured pig and cattle peripheral lymphocytes are summarized in Table 1; dose dependences of CA, CE and MI are shown in Fig. 2.

The results in cultured lymphocytes indicate a significant increase in the CA frequency at concentrations of $6 \times 10^{-4} \mathrm{M}$ for both of animal species. The statistical significance of this enhancement reached the level $\mathrm{P}<0.05$. The majority of detected aberrations were chromatide breaks while no chromatide or chromosome exchanges were found. The mitotic index was also decreased remarkably. Decreasing of MI in latest of the tested concentrations performed $78.4 \%$ of control level for cattle and $57.1 \%$ of untreated MI for pig peripheral lymphocytes (Table 2). No significant differences in the incidence of CA were found at the lower concentrations $\left(6 \times 10 \mathrm{M}^{-5}\right.$ and $\left.6 \times 10^{-6} \mathrm{M}\right)$ in cattle, however, the concentration $6 \times 10^{-5} \mathrm{M}$ yielded a statistically significant increase of CA in pig peripheral lymphocytes using the Student's $\mathrm{t}$ - test.

Neither the effect of dose nor correlation between SCE and CA was observed in pig peripheral lymphocytes. The top SCE frequency achieved $(7.28 \pm 1.01)$ at a concentration 
Table 1

Chromosome aberrations in cultured bovine and pig peripheral lymphocytes treated with supermethrin

\begin{tabular}{|c|c|c|c|c|c|c|c|c|}
\hline \multirow{2}{*}{$\begin{array}{l}\text { Tested } \\
\text { culture }\end{array}$} & \multirow[t]{2}{*}{ Dose } & \multirow{2}{*}{$\begin{array}{l}\text { No.of } \\
\text { cells }\end{array}$} & \multicolumn{4}{|c|}{ Type of aberrations* } & \multirow{2}{*}{$\begin{array}{l}\% \text { of aberrant } \\
\text { cells } \pm S D\end{array}$} & \multirow{2}{*}{$\begin{array}{c}\% \text { of breaks } \\
\pm S D\end{array}$} \\
\hline & & & $\overline{C B}$ & IB & $\overline{\mathrm{CE}}$ & IE & & \\
\hline \multicolumn{9}{|l|}{ Pig } \\
\hline \multirow{5}{*}{$\begin{array}{l}\text { Control } \\
\text { Experiment }\end{array}$} & - & 200 & 3 & - & - & - & $1.5 \pm 0.35$ & $1.5 \pm 0.35$ \\
\hline & DMSO & 200 & 4 & - & - & - & $2.0 \pm 0.00$ & $2.0 \pm 0.00^{\mathrm{a}}$ \\
\hline & $6 \times 10^{-4} \mathrm{M}$ & 200 & 13 & & & & $65+035$ & $65+035^{*}$ \\
\hline & $6 \times 10^{-5} \mathrm{M}$ & 200 & $\begin{array}{r}13 \\
8\end{array}$ & $\overline{3}$ & - & - & $5.5 \pm 0.35$ & $5.5 \pm 0.71^{*}$ \\
\hline & $6 \times 10^{-6} \mathrm{M}$ & 200 & 6 & 2 & - & - & $4.0 \pm 0.71$ & $4.0 \pm 0.71^{\mathrm{a}}$ \\
\hline \multicolumn{9}{|l|}{ Bovine } \\
\hline Control & - & 200 & 6 & - & - & - & $3.0 \pm 0.00$ & $3.00 \pm 0.00$ \\
\hline & DMSO & 200 & 7 & - & - & - & $3.5 \pm 0.35$ & $3.5 \pm 0.35^{\mathrm{a}}$ \\
\hline \multicolumn{9}{|l|}{ Experiment } \\
\hline & $\begin{array}{l}6 \times 10^{-4} \mathrm{M} \\
6 \times 10^{-5} \mathrm{M}\end{array}$ & $\begin{array}{l}200 \\
200\end{array}$ & $\begin{array}{l}14 \\
15\end{array}$ & $\begin{array}{l}3 \\
-\end{array}$ & - & - & $\begin{array}{l}8.0 \pm 0.71 \\
6.0 \pm 0.71\end{array}$ & $\begin{array}{l}8.5 \pm 1.31^{*} \\
7.5 \pm 1.06^{\mathrm{a}}\end{array}$ \\
\hline & $6 \times 10^{-6} \mathrm{M}$ & 200 & 8 & 2 & - & - & $5.0 \pm 0.00$ & $5.0 \pm 0.00^{\mathrm{a}}$ \\
\hline
\end{tabular}

CB - chromatide break, IB - isochromatide break, CE - chromatide exchange, IE - iso-chromatide exchange

${ }^{*} \mathrm{P}<0.05$ according to Student's t test and also chi ${ }^{2}$ test

a $\mathrm{P}<0.05$ according to Student's test

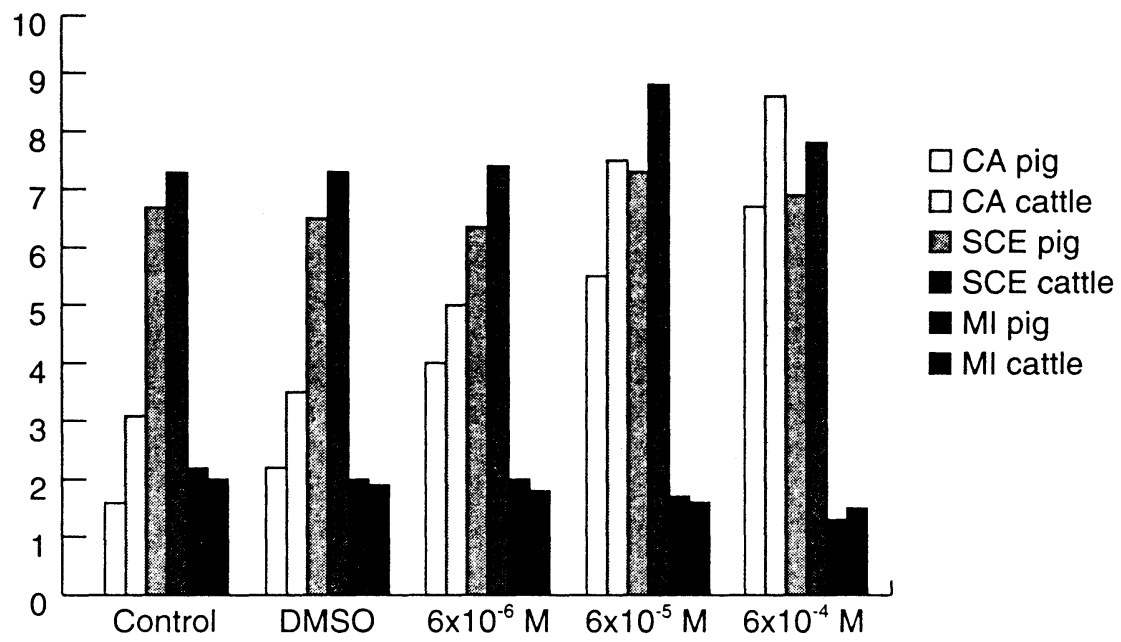

Fig. 2. Chromosome aberrations, SCE and mitotic index frequencies in pig and cattle lymphocytes after supermethrin administration

of $6 \times 10^{-5} \mathrm{M}$, was not satisfactory for statistical verification to compare to the control level caused by DMSO $(6.53 \pm 0.95)$.

Different resuls were obtained in cultured cattle lymphocytes on the other hand. Supermethrin at the concentration of $6 \times 10^{-5} \mathrm{M}$ increased the basic level of SCE significantly $(\mathrm{P}<0.05)$. However, there was no increase at the highest dose $\left(6 \times 10^{-4} \mathrm{M}\right.$, Table 3). 
Table 2

Value of mitotic index (MI) in cultured peripheral lymphocytes after supermethrin administration

\begin{tabular}{|lcrr|}
\hline Doses & $\begin{array}{c}\text { No of counted } \\
\text { cells }\end{array}$ & pig & Species \\
\hline Control & 2000 & $2.10 \pm 0.07$ & cattle \\
DMSO & 2000 & $1.95 \pm 0.35$ & $1.86 \pm 0.06$ \\
$6 \times 10^{-4}$ & 2000 & $1.2 \pm 0.07$ & $1.8 \pm 0.00$ \\
$6 \times 10^{-5}$ & 2000 & $1.7 \pm 0.07$ & $1.45 \pm 0.03$ \\
$6 \times 10^{-6}$ & 2000 & $2.05 \pm 0.11$ & $1.63 \pm 0.17$ \\
\hline
\end{tabular}

Table 3

SCE in cultured pig and cattle peripheral lymphocytes induced in vitro by supermethrin

\begin{tabular}{|lcccc|}
\hline $\begin{array}{l}\text { Tested } \\
\text { compound }\end{array}$ & Dose & $\begin{array}{l}\text { No.of } \\
\text { cells }\end{array}$ & $\begin{array}{c}\text { SCE + SD } \\
\text { pig }\end{array}$ & $\begin{array}{c}\text { SCE + SD } \\
\text { cattle }\end{array}$ \\
\hline $\begin{array}{l}\text { Control } \\
\text { (DMSO) }\end{array}$ & - & 100 & $6.67 \pm 0.95$ & $7.37 \pm 0.55$ \\
\hline Supermethrin & 100 & $6.53 \pm 0.95^{\mathrm{a}}$ & $7.30 \pm 0.49^{\mathrm{a}}$ \\
& $10^{-4}$ & 100 & $7.00 \pm 0.78$ & $7.75 \pm 0.64^{\mathrm{a}}$ \\
& $10^{-5}$ & 100 & $7.28 \pm 1.01$ & $8.67 \pm 0.64^{*}$ \\
& $10^{-6}$ & 100 & $6.37 \pm 0.95$ & $8.25 \pm 1.01^{\mathrm{a}}$ \\
\hline
\end{tabular}

${ }^{a}$ no statistical significance

$* \mathrm{P}<0.05$ according to ANOVA test

\section{Discussion}

Different results on genotoxicity of pyrethroids, including cypermethrin, have been obtained during the last ten years. Positive as well as negative results have been reached according to the utilized test and their application form. Cypermethrin was classified as a genotoxic agent by MN test in rodents (Amer et al. 1985; Bachitova and Pashin 1988), weak genotoxic agent in human lymphocyte cultures (Surralles et al. 1995) but negative results have been recorded in rat bone marrow cells (Hoellinger et al. 1987).

Cypermethrin has been found to be non-mutagenic in CA and SCE test in human peripheral lymphocytes (Puig et al. 1989) but a significant and dose-related genotoxic effect has been described in mice bone marrow and spleen cells in the same assays (Amer et al. 1993).

Cypermethrin and its analogue supercypermethrin, were evaluated as non-mutagenic in Salmonella (Miyamoto 1976; Miadokova et al. 1992). In contrast to these results cypermethrin induced sex-linked recessive lethal mutation in Drosophila (Batiste-Alentorn et al. 1986) and a slight increase of aberrant anaphases and telophases in Hordeum vulgare and Vicia faba were observed after the treatment with supercypermethrin (Miadoková et al. 1992).

The first possible cause for such increase of CA that did not correspond to its dose as detected in pig peripheral lymphocytes after supermethrin application is the elimination of cells with great chromosomal damage (Preston et al. 1987). We assumed that this hypothesis seems to be correct, because the great decrease of MI in latest of tested concentrations $6 \times 10^{-4} \mathrm{M}$.

Another substantial aspect concerning genotoxicity evaluation is the mechanism of DNA 
damage caused by the test agent. Aberrations formed in unreplicated $\mathrm{G}_{1}$ chromosomes will be duplicated in the $\mathrm{S}$-phase and will subsequently appear as chromosome-types during the next mitosis. Aberrations formed after DNA replication involve one chromatide only and will be recognized as chromatide types (B arrueco et al. 1992). The aberrations induced by supermethrin were mainly of the chromatide-type. Only one-fifth of the detected chromosomal aberrations could be characterized as the chromosome-type.

The frequency of aberrations formed by supermethrin during the in vitro assay was doserelated in cattle peripheral lymphocytes. However, the significant clastogenic effect was only found at the concentration $6 \times 10^{-4} \mathrm{M}$. This finding corresponds to our previous results achieved in sheep in in vitro conditions (Dianovský and Šiviková 1995) and indicates a lower sensitivity to the tested agent for ruminants.

A linear relationship was established between frequencies of SCE and gene mutations in V 79 and CHO cells and in human lymphocytes for a limited number of chemical mutagens and gene loci (Carra no and Tho mps on 1982). These results suggest a similarity between gene mutations and SCE formation with regard to types of lesion involved, or the processing of the lesions (IARC 1986).

The frequency of SCE formed by supermethrin in the in vitro assay in cattle was significant for $6 \times 10^{-5} \mathrm{M}(\mathrm{P}<0.05)$, but not for the highest tested concentration $\left(6 \times 10^{-4} \mathrm{M}\right)$. No dose-related and no significant SCE induction were detected in pig peripheral lymphocytes. Thus, the induction of SCE is of no biological importance because of the absence of dose relation and corresponding results in different animal species.

We conclude that supermethrin failed to induce significant and dose-related chromosomal damage. The clastogenic effect occurred at $6 \times 10^{-4} \mathrm{M}$ in in vitro conditions for both species. This concentration is very high and not applicable when used in agriculture. Supermethrin further failed to induce significant and dose-related SCE increase. Therefore, its genotoxic potential seems to be S-phase independent. The tested agent could be characterized as more cytotoxic than clastogenic or genotoxic.

\section{Cytogenetický účinok supermetrínu v periférnych lymfocytoch ošípaných a hovädzieho dobytka}

Syntetický insekticíd supermetrín (RS)-alfa-cyano-3-fenoxy- benzyl-(1RS)-cis-3 (2,2-dichlorvinyl)-2,2-dimetyl cyklopropan carboxylát, bol testovaný na svoju klastogénnu aktivitu v pokusoch in vitro. Ako materiál boli použité kultivované periférne lymfocyty hovädzieho dobytka a ošípaných bez prítomnosti S-9 mix frakcie. Pre metabolickú aktiváciu sa využil vlastný aktivačný systém erytrocytov pri kultivácii plnej krvi. Finálne koncentrácie hodnoteného preparátu boli $6 \times 10^{-6} \mathrm{M}, 6 \times 10^{-5} \mathrm{M}$ a $6 \times 10^{-4} \mathrm{M}$. V periférnych lymfocytoch teliat nemal supermetrin klastogénny účinok v koncentráciách $6 \times 10^{-6} \mathrm{M}$ a $6 \times 10^{-5} \mathrm{M}$. Najvyššia sledovaná koncentrácia bola pozitívna $(\mathrm{p}<0.05)$ a súčasne znižovala mitotický index (MI). V kultúrach periférnych lymfocytov ošípaných sa klastogénny účinok zistil s rovnakou významnostou pre koncentrácie $6 \times 10^{-5} \mathrm{M}$ a $6 \times 10^{-4} \mathrm{M}$, súčasne $s$ výraznejším cytotoxickým účinkom vyjadreným hodnotou MI. Supermetrín bol hodnotený aj metódou sesterských chromatidových výmen (SCE) v kultúrach lymfocytov obidvoch spomenutých druhov bez zistenia korelácie medzi jeho koncentráciou a genotoxickým účinkom. Testovaný pyretroid bol charakterizovaný skôr ako cytotoxický než klastogénny alebo genotoxický. 


\section{References}

AMER, S. E., ABOUL-ELA. E. I. 1984: Cytogenetics effect of pesticides III.Induction of micronuclei in mouse bone marrow by the insecticides cypermethrin and rotenone. Mutat. Res. 155:135-142

AMER, S. E., IBRAHIM, A. A.. SHERBENY, K. M. 1993: Induction of chromosomal aberrations and sister chromatid exchange in vivo and in vitro by the insecticide cypermethrin. J. Appl. Toxicol. 13:341-345

BACHITOVA, L. M.. PAŠIN. J. V. 1988: Indukcija cipermetrinom mikrojader $v$ somatičeskich kletkach mlekopitajuščich. Citol. i genet. 22:32-35

BARRUECO, C., HERRERA. A.. COVADONGA. C., DE LA PENA. E. 1992: Cytogenetic effect of permethrin in cultured human lymphocytes. Mutagenesis 7:433-437

BATISTE-ALENTORN, M., XAMENA, N., VELASQUEZ, A., CREUS, A., MARCOS, R. 1986: Mutagenicity testing of the pyrethroid insecticide cypermethrin in Drosophila. Mutagenesis 1:343-346

CANTELLI-FORTI, G., PAVLINI, M., HRELIA. P., CORSI, C., BRONCETTI, G. 1988: Genetic activity of 2aminofluoren in the Salmonella erythrocyte mutagenicity assay. Mutat. Res. 196:83

CARRANO, A. V., THOMPSON, L. H. 1982: Sister chromatid exchange and single gene mutation. Cytogenet. and cell genet. 33:57-61

CRAWFORD, M. J., GROUCHER, A., HUTSON, D. H. 1982: The metabolism of the pyretroide insecticide cypermethrin in rats excreted metabolites. Pestic. Sci. 12:399-411

DIANOVSKÝ, J., ŠIVIKOVÁ. K. 1995: In vivo and in vitro cytogenetic effect of supermethrin. Biomed. and Environ. Sci. 8:359-366

ERIKSSON, P., NORDBERG, A. 1990: Effect of two pyrethroids, bioallethrin and deltamethrin on subpopulations of muscarinic receptors in neonatal mouse brain. Toxicol. Appl. Pharmacol. 102:453-456

HOELLINGER, H., LECORSIER. A., SONIER, M., LEGER, C., DO- CAO-THANG-NGUYEN-HOANG-NAM 1987: Cytotoxicity, cytogenotoxicity and allerginicity tests of certain pyrethroids. Drug Chem. Toxicol. 10:291-310

IARC, Report 7 1986: Assays for genetic damage in mammalian cells. Long-term and short-term screening assays for carcinogenesis: a critical appraisal. IARC Scientific Publication 83, Lyon, pp. 167-243

LEGÁTH, J., NEUSCHL, J., KAĆMAR, P., PORÁČOVÁ, J., DUDRÍKOVÁ, E., MLYNARČIKOVÁ, H., KOVAĆ, G., JAVORSKÝ, P. 1992: Clinical signs and mechanism of supermethrin intoxication in sheep. Vet. Hum. Toxicol. 34:453-455

MIADOKOVÁ, E., VLČKOVÁ, V., DÚHOVÁ, V., TREBATICKÁ, M., GARAJOVÁ, L., GROLMUS, J., PODSTÁVKOVÁ, S., VLČEK, D. 1992: Effect of supercypermethrin, a synthetic developmental pyrethroid on four biological test systems. Mutat. Res. 280:161-168

MIYAMOTO, J. 1976: Metabolism, degradation and toxicity of synthetic pyrethroids. Environ. Health Perspect. 34:15-28

PERRY, P.. WOLFF, S. 1974: New Giemsa method for differential staining of sister chromatide. Nature 251:156-158

PRESTON, R. J., SAN SEBASTIAN, R., MC FEE, A. F. 1987: The in vitro human lymphocyte assay for assessing the clastogenicity of chemical agents. Mutat. Res. 189:175-183

PUIG, M., CARBONELL, E., XAMENA, N., CREUS, A., MARCOS, R. 1989: Analysis of cytogenetic damage induced in cultured human lymphocytes by the pyrethroid insecticides cypermethrin and fenvalerate. Mutagenesis 4:72-74

SURRALLES, J., XAMENA, N., CREUS, A., CATALAN, J., NORPPA, H., MARCOS, R. 1995: Induction of micronuclei by five pyrethroid insecticides in whole-blood and isolated human lymphocyte cultures. Mutat. Res. 341:169-184

Address for correspondence:

Doc. MVDr. J. Dianovský

Department of Veterinary Genetics

University of Veterinary Medicine

Komenského 73

04181 Košice

Slovak Republic

Phone: 421953211115

Fax: 42195767675

E-mail:VETUNIV@CSEARN 